\title{
CpG oligodeoxynucleotides augment antitumor efficacy of folate receptor $\alpha$ based DNA vaccine
}

\author{
ZHENG QIU $^{1}$, LIJUN XING ${ }^{1}$, XUEQING ZHANG ${ }^{1}$, XU QIANG $^{1}$, YIFENG XU $^{1}$, \\ MEI ZHANG ${ }^{1}$, ZHENGPIN ZHOU ${ }^{1}$, JUAN ZHANG ${ }^{1}$, FANG ZHANG $^{2}$ and MIN WANG ${ }^{1}$ \\ ${ }^{1}$ School of Life Science and Technology, China Pharmaceutical University, Nanjing, Jiangsu 210009; \\ ${ }^{2}$ Jiangsu Collaborative Innovation Center of Chinese Medicinal Resources Industrialization, \\ School of Pharmacy, Nanjing University of Chinese Medicine, Nanjing, Jiangsu 210023, P.R. China
}

Received October 26, 2016; Accepted April 24, 2017

DOI: $10.3892 /$ or.2017.5633

\begin{abstract}
Folate receptor $\alpha(\mathrm{FR} \alpha)$ is overexpressed in a variety of solid tumors and has become an attractive target antigen for immunotherapy purposes. A DNA vaccine was generated by ligation of FR $\alpha$ cDNA into the eukaryotic vector pcDNA3.1. Expression of FR $\alpha$ was confirmed in transiently transfected B16 cells. B16 cell lines that stably express FR $\alpha$ were set up by G418 selection. A total of $100 \mu \mathrm{g}$ purified plasmid DNA alone or in combination with $\mathrm{CpG}$ oligodeoxynucleotides (CpG ODN) was injected intramuscularly in C57BL/6 mice four times at one week intervals. ELISA analysis confirmed that high titers of antibodies against FR $\alpha$ existed in the sera of the experimental animals. Specific cytotoxic T lymphocyte activity against FR $\alpha$-expressing B16 cells was found and FR $\alpha$ specific lymphocyte proliferation was detected. Coinjection of CpG ODN increased both humoral and cellular immune responses. In the protective model, in which C57BL/6 mice were immunized with the FR $\alpha$ DNA vaccine four weeks before tumor cell inoculation, the growth of tumor was significantly inhibited, and the presence of CpG ODN further increased the inhibitory effect. FR $\alpha$ DNA vaccine alone did not show a significant inhibitory effect in the therapeutic model, in which the DNA vaccine was immediately injected after tumor inoculation. However, FR $\alpha$ DNA vaccine plus $\mathrm{CpG}$ ODN showed a significant inhibitory effect in tumor growth. Survival curves for both animal experiments confirmed that mice immunized
\end{abstract}

Correspondence to: Professor Min Wang, School of Life Science and Technology, China Pharmaceutical University, Nanjing, Jiangsu 210009, P.R. China

E-mail: minwang@cpu.edu.cn

Abbreviations: $\mathrm{FR} \alpha$, folate receptor $\alpha$; $\mathrm{CpG}$ ODN, CpG oligodeoxynucleotides; CTL, cytotoxic T lymphocyte; TLR9, toll-like receptor 9; GPI, glycosylphosphatidylinositol; 5-MTHF, 5-methyltetrahydrofolate; i.m., intramuscular; LDH, lactate dehydrogenase; E:T ratio, effector cells : target cells ratio

Key words: immunotherapy, FR $\alpha$, DNA vaccine, $\mathrm{CpG}$ ODN, cancer with pcDNA3.1/FR $\alpha$ plus $\mathrm{CpG}$ ODN had a significantly prolonged survival period than that of the pcDNA3.1 control group, the CpG ODN group or the pcDNA3.1/FR $\alpha$ group. The above showed that human FR $\alpha$ based DNA vaccination with CpG ODN as an adjuvant was effective in growth inhibition of a FR $\alpha$ expressing tumor in mice and deserves further evaluation as a possible immunotherapy.

\section{Introduction}

Conventional cancer treatments include chemotherapy, surgery and radiation. They are not very effective in controlling cancers and bring huge suffering to the patients. Novel therapies need to be developed for cancer treatment $(1,2)$.

Most tumor cells express specific antigens that are not found on normal cells. Those so-called tumor-associated antigens allow tumor cells to be recognized and destroyed by the immune system (3). Triggering antitumor immunity by specific vaccination is a safe and effective way to control tumor growth. Comparing with conventional vaccinations such as whole tumor cells, proteins or derived peptides, DNA vaccination is a relatively new method (4). DNA vaccination can generate both humoral and cellular immune responses. Cytotoxic T lymphocyte (CTL) response is regarded critical for tumor cell killing. Furthermore, plasmid DNA is relatively easy to be manipulated to encode desired tumor associated antigens and can be manufactured in large scale without stringent condition requirements compared with protein vaccines, which provides a more practical approach for vaccine development (5).

Although plasmid DNA vaccines are safe and easy to prepare, they are poorly immunogenic molecules. Thus, in order to augment immune responses, a variety of adjuvants have been utilized (6). CpG oligodeoxynucleotides (CpG ODN) are small DNA molecules mimicking the unmethylated CpG motifs which frequently present in bacterial DNA. In mammals, these specific DNA motifs bind and activate tolllike receptor 9 (TLR9), leading to activation, maturation, and proliferation of immune cells. TLR9 is localized in endoplasmatic reticulum, late endosomal and lysosomal compartments of the intracellular milieu. Thus, internalization of pathogenderived DNA is required for TLR9 triggering, an outcome 
that results from either intracellular infection or uptake of bacterial/viral particles by immune cells (7). Once stimulated, TLR9 initiates a response biased towards proinflammatory/ Th1 immunity (8). Extensive animal experiments showed that CpG ODN could support the induction of Ag-specific immunity against co-administered peptides and vaccines (9). The early phase I trials showed that CpG ODN was safe and could improve the immunogenicity of co-administered vaccines (10). To increase their DNase resistance, CpG-ODN can be synthesized with a phosphorothioate backbone (11-13).

Folate receptor $\alpha(\mathrm{FR} \alpha)$ is a $38 \mathrm{kDa}$ glycosylphosphatidylinositol (GPI)-anchored glycoprotein. It binds folic acid and 5-methyltetrahydrofolate (5-MTHF) with high affinity (14). FR $\alpha$ expression in normal tissues is highly restricted and inaccessible to the normal circulation. High expressions of FR $\alpha$ have been described in some cancers, such as non-mucinous ovarian, endometrial, non-small cell lung carcinomas and to a lesser extent in clear cell renal, colorectal and breast cancers. Moreover, FR $\alpha$ expression has been observed in nearly $90 \%$ of non-mucinous ovarian cancer and correlated with tumor grade, stage, and aggressiveness. Furthermore, FR $\alpha$ expression remains unchanged in epithelial ovarian and endometrial cancer after chemotherapy. Based on its highly tumor restricted expression profile, FR $\alpha$ represents an attractive candidate for cancer diagnostics and therapeutics (15-19). Several FR-targeted agents are currently in development, representing a promising approach for relevant cancer treatments (20-22).

In this study, we assembled a cytomegalovirus promoter expression vector containing human FR $\alpha$ cDNA, and we evaluated its ability to induce an immune response in mice. We detected both FR $\alpha$-specific antibodies and cytotoxic $\mathrm{T}$ lymphocyte responses, which significantly reduced the 'in vivo' growth of FRa expressing tumor cells. In addition, the adjuvant effect of $\mathrm{CpG}$ ODN was confirmed.

\section{Materials and methods}

Reagents, cell lines and animals. CpG ODN was customsynthesized by Sangon Biotech (Shanghai, China). The sequence of stimulatory phosphorothioate $\mathrm{CpG}$ ODN was: 5'-TCCATGACGTTCCTGACGTT-3'. Recombinant human folate receptor $\alpha$ protein, rabbit polyclonal anti-FR $\alpha$ antibody (antigen affinity purified), HRP conjugated goat anti-mouse IgG secondary antibody and HRP conjugated goat anti-rabbit IgG secondary antibody were purchased from Sino Biological Inc. (Beijing, China). G418 sulfate and plasmid purification kits were from Sangon Biotech and Lipofectamine 2000 was purchased from Invitrogen (Carlsbad, CA, USA). Lactate dehydrogenase (LDH) kits were purchased from Jiancheng Bioengineering Institute (Nanjing, China).

The ovarian cancer cell line SKOV3 and metastatic melanoma B16 cell line were from Shanghai Cell Biology Institutes (Academia Sinica, Shanghai, China) and were maintained in Dulbecco's modified Eagle's medium (Gibco, Carlsbad, CA, USA) with $10 \%$ fetal bovine serum and antibiotics.

Female C57BL/6 (6 weeks, 18-20 g) were purchased from the Yangzhou University Animal Center and used under the experimental animal production license 2121922. All animals were housed in a controlled environment $\left(25^{\circ} \mathrm{C} ; 12 \mathrm{~h}\right.$ lightdark cycle), with water and food provided freely. The authors confirm that experiments involving animals adhered to the ethical standards of China Pharmaceutical University and the care of animals was in accordance with the licensing guidelines of China Pharmaceutical University.

DNA vaccine construction. Total RNA was isolated from human ovarian cancer SKOV3 cells. The DNA fragment encoding FR $\alpha$ was amplified using RT-PCR. Reverse transcription was performed at $42^{\circ} \mathrm{C}$ using oligo $\mathrm{d}(\mathrm{T})_{15}$ as a primer and PCR amplification was carried out for 30 cycles (1 min at $94^{\circ} \mathrm{C}, 1 \mathrm{~min}$ at $55^{\circ} \mathrm{C}, 1 \mathrm{~min}$ at $72^{\circ} \mathrm{C}$ ) using the following primers specific for FR $\alpha$ gene amplification: CAGTAAGCTTGC CATGGCTCAGCGGATGA (HindIII); CCGGAATTCTCA GCTGAGCAGCCACAGC (EcoRI). The gene was cloned into the eukaryotic vector pcDNA3.1 and the constructed recombinant plasmid was identified by restriction endonuclease digestion and DNA sequencing.

Expression of recombinant plasmid encoding FR $\alpha$. B16 cells were transfected with a recombinant plasmid pcDNA3.1/FR $\alpha$ or a control plasmid pcDNA3.1 using Lipofectamine 2000 according to the manufacturer's instructions. After incubation for $72 \mathrm{~h}$, the cells were harvested and tested for FR $\alpha$ expression by RT-PCR, western blotting and immunofluorescence. For RT-PCR, the total RNA was isolated and reverse transcribed into cDNA. FR $\alpha$ gene was amplified using previously described primers and analyzed by electrophoresis. For western blotting, collected cell lysates were resolved by polyacrylamide gel electrophoresis and the protein bands were transferred onto a membrane. The membrane was blocked with 5\% nonfat dry milk and FR $\alpha$ was detected with rabbit polyclonal anti-FR $\alpha$ antibodies (1:5000) followed by HRP conjugated second antibodies (1:5000). The protein band was visualized with an enhanced ECL chemiluminescent reagent using a Bio-Rad detection system. For cell immunofluorescence staining, the cells were fixed with $4 \%$ polyoxymethylene for $20 \mathrm{~min}$. After washing with PBS, the cells were treated with Triton X-100 for 10 min and blocked with 5\% BSA for $1 \mathrm{~h}$. Then the cells were incubated with rabbit polyclonal anti-FR $\alpha$ antibodies (1:100) at $4^{\circ} \mathrm{C}$ overnight. After being washed with PBS, the cells were incubated with FITC-conjugated goat anti-rabbit IgG secondary antibodies (1:100) for $2 \mathrm{~h}$ and visualized with a fluorescent microscope (Olympus) and photographed.

Plasmid DNA preparation. Plasmid DNA was propagated in E. coli and was isolated using endonuclease-free plasmid purification kits according to the supplier's protocol. The purified plasmids were dissolved in sterile PBS and used for injection or stored at $-80^{\circ} \mathrm{C}$ until use.

Preparation of FR $\alpha$-expressing tumor cell lines. B16 cells were transfected with pcDNA3.1/FR $\alpha$ using Lipofectamine 2000 as described by the manufacturer. After incubation with DNA-lipid complex for $24 \mathrm{~h}$, cells were cultured in fresh growth medium (RPMI-1640 containing 10\% fetal bovine serum) with $1000 \mu \mathrm{g} / \mathrm{ml}$ antibiotics G418 for 2 weeks. A G418 dose-response curve was established prior to the selection of the cells. The resistant cells were obtained and serially diluted. Single cells were picked and cultured in presence of G418 for another two weeks to obtain cells that stably express FR $\alpha$. 
Immunization. Wild-type female C57BL/6 mice (4-6 weeks old) were randomly divided into 4 groups with 6 mice in each group. Preliminary experiments were performed to compare the stimulating effect of $\mathrm{CpG}$ ODN at different dosages and it was found that $10 \mu \mathrm{g} \mathrm{CpG} \mathrm{ODN} \mathrm{was} \mathrm{a} \mathrm{proper} \mathrm{dosage} \mathrm{(data}$ not shown). In the following immunization, we used $10 \mu \mathrm{g}$ CpG ODN per mice. Mice receiving a blank vector or $10 \mu \mathrm{g}$ CpG ODN served as the control groups. In the third group, mice were administered with $100 \mu \mathrm{g}$ recombinant plasmid pcDNA3.1/FR. In the fourth group mice were injected with $100 \mu \mathrm{g}$ pcDNA3.1/FR Plus $10 \mu \mathrm{g} \mathrm{CpG} \mathrm{ODN.} \mathrm{All} \mathrm{the} \mathrm{reagents}$ were injected in the rectus femoris muscle of both hind legs. Four identical injections were given at one week intervals.

Antibody detection. One week after the fourth immunization, blood samples were collected through the canthus and were kept at $4^{\circ} \mathrm{C}$ for $30 \mathrm{~min}$. Then the blood samples were centrifuged at $1500 \mathrm{x}$ g for $10 \mathrm{~min}$, and the supernatants were taken and stored at $-80^{\circ} \mathrm{C}$ until detection. Microtiter plates (96-well) were coated with $100 \mu \mathrm{l}$ of $1 \mu \mathrm{g} / \mathrm{ml}$ recombinant human FR $\alpha$ in $0.05 \mathrm{M}$ sodium bicarbonate $(\mathrm{pH} 9.6)$ and the plate was kept overnight at $4^{\circ} \mathrm{C}$. After washing three times, the plate was blocked with $0.1 \mathrm{M}$ PBS (pH 7.4) containing $10 \%$ (V/V) skim milk at $37^{\circ} \mathrm{C}$ for $1.5 \mathrm{~h}$. Then, serial dilutions of mouse sera (diluted in PBS/0.1\% BSA/0.05\% Tween-20) were added and incubated for $2 \mathrm{~h}$ at $37^{\circ} \mathrm{C}$. After washing three times, $100 \mu \mathrm{l}$ of HRP-conjugated sheep anti-mouse IgG (1:5000) was added and incubated for $1 \mathrm{~h}$ at $37^{\circ} \mathrm{C}$. After washing, tetramethylbenzidine (TMB) substrate (100 $\mu \mathrm{l} /$ well) was added and incubated for $15 \mathrm{~min}$. The reactions were stopped with $2 \mathrm{M}$ sulfuric acid ( $50 \mu \mathrm{l} /$ well). The absorbance of each well at $450 \mathrm{~nm}$ was detected with an automated ELISA reader.

Cytotoxic T-lymphocyte (CTL) assays. One week after the last immunization, spleens were isolated from three sacrificed mice of each immunized group. The spleens were ground and passed through a $100 \mu \mathrm{m}$ filter under sterile conditions. Erythrocytes were lysed using Tris- $\mathrm{NH}_{4} \mathrm{Cl}$ ( $\mathrm{pH}$ 7.2). Splenocytes were washed by PBS and resuspended in RMPI-1640 containing $10 \%$ FBS. Then splenocytes of each group were cultured in the presence of $10 \mu \mathrm{g} / \mathrm{ml}$ recombinant human FR $\alpha$ for five days and used as effector cells. The FR $\alpha$ expressing tumor cells were used as target cells. Cytotoxic activity was determined using a lactate dehydrogenase kits. Effector cells were mixed with target cells $\left(5 \times 10^{4}\right.$ cells) in triplicate with E:T (effector cells : target cells) ratios of 50:1, 25:1 and 12.5:1. The mixture cells were co-cultured for $4 \mathrm{~h}$ at $37^{\circ} \mathrm{C}$ in an atmosphere containing $5 \% \mathrm{CO}_{2}$. LDH release under each condition was evaluated according to the instructions of the manufacturer. Cytotoxicity was calculated using the following equation: cytotoxicity $(\%)=\left[\left(\mathrm{OD}_{\text {experiment }}-\mathrm{OD}_{\text {effector spontaneous }}-\mathrm{OD}_{\text {target spon- }}\right.\right.$ taneous $\left.) /\left(\mathrm{OD}_{\text {target maximum }}-\mathrm{OD}_{\text {target spontaneous }}\right)\right] \times 100 \%$.

Lymphocyte proliferation assay. One week after the last immunization, the splenocytes were isolated from each immunized group as described above. Splenocytes $\left(1 \times 10^{5}\right)$ were cultured in $100 \mu \mathrm{l}$ culture medium as blank, or co-cultured with different stimulants including BSA $(100 \mu \mathrm{g} / \mathrm{ml})$ as non-relevant peptide control, recombinant human FR $\alpha(100 \mu \mathrm{g} / \mathrm{ml})$ or $100 \mu \mathrm{g} / \mathrm{ml}$ ConA. Cells were cultured in triplicates in 96-well, flat-bottom plates at $37^{\circ} \mathrm{C}$ for $72 \mathrm{~h}$ in a $5 \% \mathrm{CO}_{2}$ incubator. MTT dissolved in PBS was added to the cultures at a final concentration of $0.5 \mathrm{mg} / \mathrm{ml}$ and incubated at $37^{\circ} \mathrm{C}$ for $4 \mathrm{~h}$ to form formazan crystals, which were later dissolved in DMSO. The optical density was measured at $540 \mathrm{~nm}$ on a Multimode plate Reader. The results were analyzed as the stimulate index (SI) defined as $\mathrm{OD}_{\text {experiment }} / \mathrm{OD}_{\text {blank / pcDNA3.1. }}$.

Evaluation of the protective effect in C57BL/6 mice. Female C57BL/6 mice (4-6 weeks) were used to evaluate tumor growth inhibition. Immunization procedure was as described above. One week after the final immunization (week 5), the mice were challenged intradermally in the right flank with $2 \times 10^{5}$ FR $\alpha$ expressing B16 cells. Tumor width and length were measured with a caliper periodically and tumor volume was calculated as $\mathrm{V}=\left(\right.$ length $\mathrm{x}$ width $\left.{ }^{2}\right) / 2$. In the survival experiment, the animals were kept for 50 days or until death after tumor challenge.

Evaluation of the therapeutic effect in C57BL/6 mice. Female C57BL/6 mice (4-6 weeks) were challenged with FR $\alpha$ expressing B16 cells on day 0. Four times immunizations with one week intervals were followed as described. Tumor growth was monitored and tumor volume was calculated. In the survival experiment, the animals were kept for 50 days or until death after tumor challenge.

Analysis of FR $\alpha$ protein expression in tumor tissues. Tumor tissues from experimental mice were collected, ground and lysed in RAPI buffer. The proteins were extracted and resolved by SDS-PAGE. Then western blotting was used to detect FR $\alpha$ expression in tumor tissues.

Statistical analysis. Data were expressed as mean \pm SD. A two-tailed Student's t-test was used to analyze significance among the groups. A value of $\mathrm{P}<0.05$ was considered statistically significant; $\mathrm{P}<0.01$ was considered highly statistically significant.

\section{Results}

DNA vaccine construction. Human FR $\alpha$ gene was assembled into the pcDNA3.1 expression plasmid under the transcriptional control of a cytomegalovirus promoter. The resulting plasmid

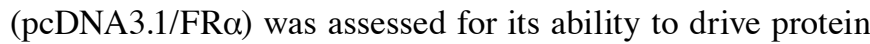
synthesis by transient transfection of B16 cells. FR $\alpha$ expression on mRNA level was confirmed with RT-PCR (Fig. 1A) and its expression on a protein level was detected with western blot analysis (Fig. 1B) and immunofluorescence staining (Fig. 1C). These data indicated that the plasmid was functional and capable of inducing expression of the encoded antigen.

Establishment of FR $\alpha$ expressing tumor cell lines. Cells were transfected with pcDNA3.1/FR $\alpha$. FR $\alpha$ expressing cells were selected with G418 for two weeks. Only the cells with the foreign gene integrated into their genomes could proliferate in the presence of G418. By serial dilution, two FR $\alpha$ expressing B16 cell lines (B62 and C411) were established. Immunofluorescence staining showed that all the cells present in the picture expressed FR $\alpha$ (Fig. 2). 

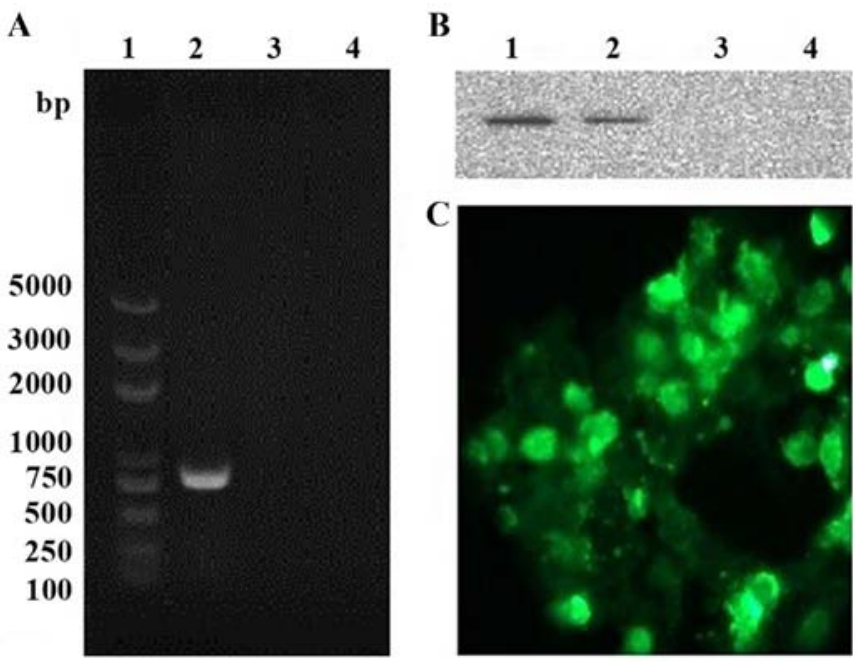

Figure 1. Expression of FR $\alpha$ in pcDNA3.1/FR $\alpha$ transfected B16 melanoma cells. (A) FR $\alpha$ mRNA was detected with RT-PCR. Lane 1, DNA marker; lane 2, B16 cells transfected with pcDNA3.1/FR $\alpha$; lane 3, B16 cells transfected with pcDNA3.1; lane 4, B16 cells without transfection. (B) FR $\alpha$ protein was detected with western blotting. Lane $1, \mathrm{FR} \alpha$ recombinant protein as a control; lane 2, lysate of B16 cells that were transfected with pcDNA3.1/FR $\alpha$; lane 3, lysate of B16 cells transfected with pcDNA3.1; lane 4, lysate of B16 cells without transfection. (C) Detection of FR $\alpha$ protein expression on the surface of pcDNA3.1/FR $\alpha$ transfected B16 cells detected by immunofluorescence staining (magnification, $\mathrm{x} 400$ ).
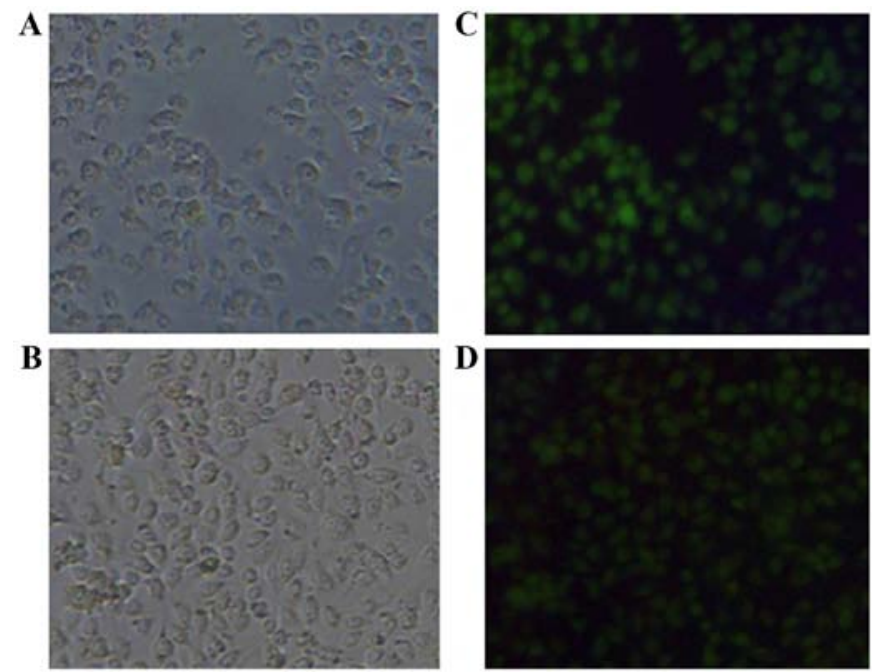

Figure 2. Immunofluorescence staining of two G418 resistant FR $\alpha$-expressing B16 cell lines C411 (A and B) and B62 (C and D) (magnification, $\mathrm{x} 400$ ).

Humoral immunity induced by the DNA vaccine. To investigate humoral immune response in the mice vaccinated with pcDNA3.1/FR $\alpha$, mice were immunized four times at one week intervals by intramuscular injections. Serum samples were collected one week after the last immunization and tested by ELISA for their reactivity with recombinant FR $\alpha$. As shown in Fig. 3, pcDNA3.1/FR $\alpha$ vaccine elicited antibodies against $\mathrm{FR} \alpha$, displaying a very significant difference compared with the pcDNA3.1 group $(\mathrm{P}=0.00756)$. The group injected with pcDNA3.1/FR $\alpha$ in combination with CpG ODN showed a very significant difference compared with the pcDNA3.1 group $(\mathrm{P}=0.00726)$ and with the $\mathrm{CpG}$ ODN group $(\mathrm{P}=0.00651)$

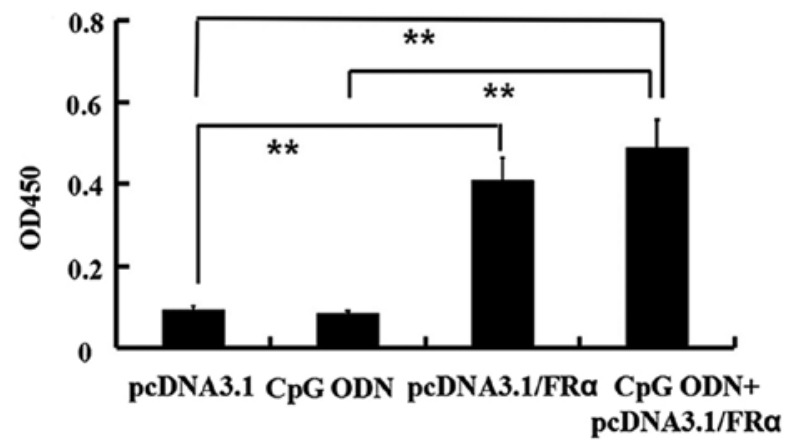

Figure 3. Generation of anti-FR $\alpha$ antibodies in immunized mice. Mice were injected with pcDNA3.1, CpG ODN, pcDNA3.1/FR $\alpha$ alone or in combination with $\mathrm{CpG}$ ODN once a week. After four weeks of treatment, blood samples were collected and antibody levels were tested by ELISA. ${ }^{* *} \mathrm{P}<0.01$.

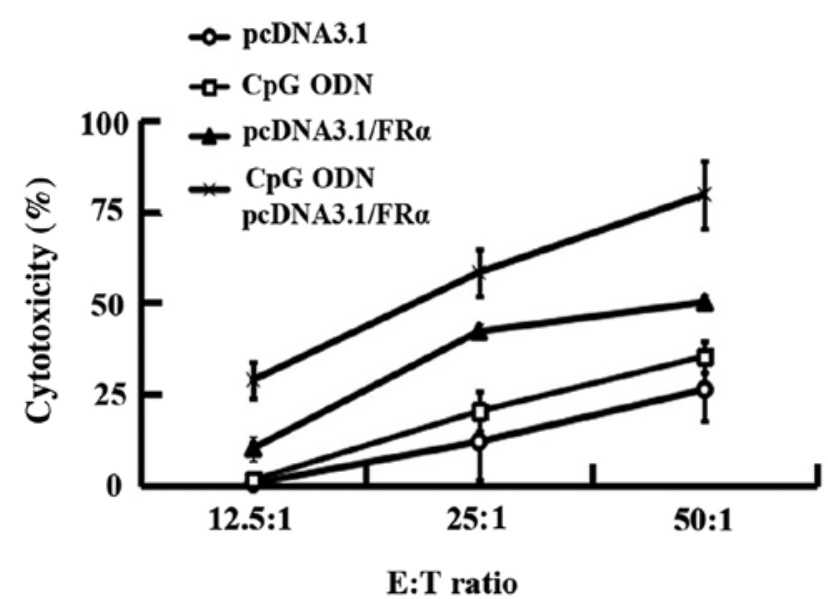

Figure 4. FR $\alpha$ specific CTL activities in immunized mice. Splenocytes isolated from immunized mice of each group were cultured with FR $\alpha$ recombinant protein for five days and used as effector cells. Cytotoxic activity was determined by LDH assay using FR $\alpha$ expressing B16 cells as target cells.

whereas there was not a significant difference compared with the pcDNA3.1/FR $\alpha$ group $(\mathrm{P}=0.7119)$.

Cytotoxic T-lymphocyte (CTL) assays. The FR $\alpha$ specific CTL activities of splenocytes from immunized C57BL/6 mice were assessed with FR $\alpha$ expressing B16 cells as target cells using a $\mathrm{LDH}$ release method. The effect of pcDNA3.1/FR $\alpha$ plus $\mathrm{CpG}$ ODN was tested in comparison with the groups treated with pcDNA3.1, CpG ODN or pcDNA3.1/FR $\alpha$ (Fig. 4). Four injections of pcDNA3.1/FR $\alpha$ resulted in a mean specific killing rate of $10 \%$ (E:T ratio of 12.5:1), 42\% (E:T ratio of 25:1) or $50 \%$ (E:T ratio of 50:1). These killing rates were significantly higher than those of pcDNA3.1 treatment group with P-values of $0.013,0.012$ and 0.016 for the E:T ratio of 12.5:1, 25:1 and $50: 1$. The killing rates of combined immunization group with pcDNA3.1/FR $\alpha$ and CpG ODN were 28\% (E:T ratio of 12.5:1), $58 \%$ (E:T ratio of $25: 1$ ) or $79 \%$ (E:T ratio of 50:1), which were much higher than those of the pcDNA3.1 group $(\mathrm{P}<0.001)$ and the $\mathrm{CpG}$ ODN group $(\mathrm{P}<0.001)$ at the corresponding E:T ratio. Furthermore, the killing rates of combined immunization group (pcDNA3.1/FR $\alpha$ and $\mathrm{CpG}$ ODN) were higher than the pcDNA3.1/FR $\alpha$ immunized group with P-values of 0.011 , 0.024 and 0.010 at the E:T ratio of 12.5:1, 25:1 and 50:1. 


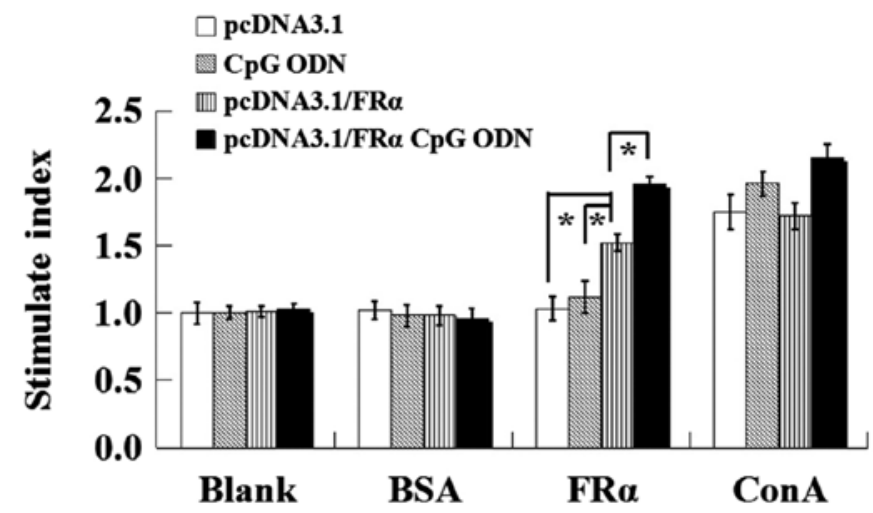

Figure 5. FR $\alpha$ specific lymphocyte proliferation. Mice were injected with pcDNA3.1, pcDNA3.1/FR $\alpha$, pcDNA3.1/FR $\alpha$ in combination with $10 \mu \mathrm{g} \mathrm{CpG}$ ODN once a week. One week after the fourth immunization, the splenocytes were isolated and cultured without or with different stimulants (BSA, recombinant human FR $\alpha$ or ConA) for $72 \mathrm{~h}$. MTT method was used to test the cell proliferation. The results were analyzed with the Stimulate Index (SI) defined as $\mathrm{OD}_{\text {experiment }} / \mathrm{OD}_{\mathrm{pcDNA3} \text {.1 group in the blank group. }}{ }^{*} \mathrm{P}<0.05,{ }^{* *} \mathrm{P}<0.01$.
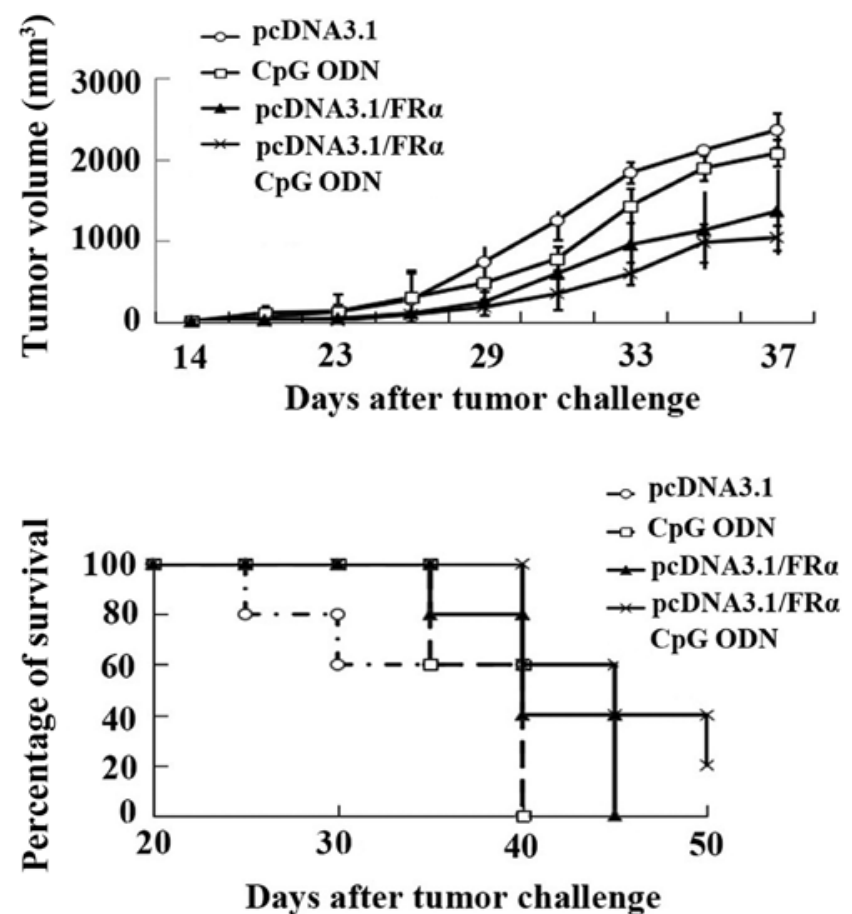

Figure 6. Immunization of mice with pcDNA3.1/FR $\alpha$ alone or in combination with CpG ODNs inhibited the growth of FR expressing tumors and prolonged their survival. Female C57BL/6 mice were vaccinated at a one week interval with pcDNA3.1, CpG ODNs, pcDNA3.1/FR $\alpha$ and pcDNA3.1/ $\mathrm{FR} \alpha$ plus $\mathrm{CpG}$ ODNs. After four times vaccination, mice were subcutaneously inoculated with FR $\alpha$ expressing B16 cells. Tumor volume was measured for 37 days after tumor challenge (upper panel). Mouse survival rates were monitored for 50 days (lower panel).

Lymphocyte proliferation assays. By treating the isolated lymphocytes with recombinant human $\mathrm{FR} \alpha$, the antigen specific lymphocyte proliferation of immunized C57BL/6 mice was measured using a MTT method and compared with the non-relevant peptide group and the mitogen ConA group. As shown in Fig. 5, there was no proliferation in the blank group or the non-relevant peptide group. With FR $\alpha$ as a stimulant, the stimulate index of mice immunized
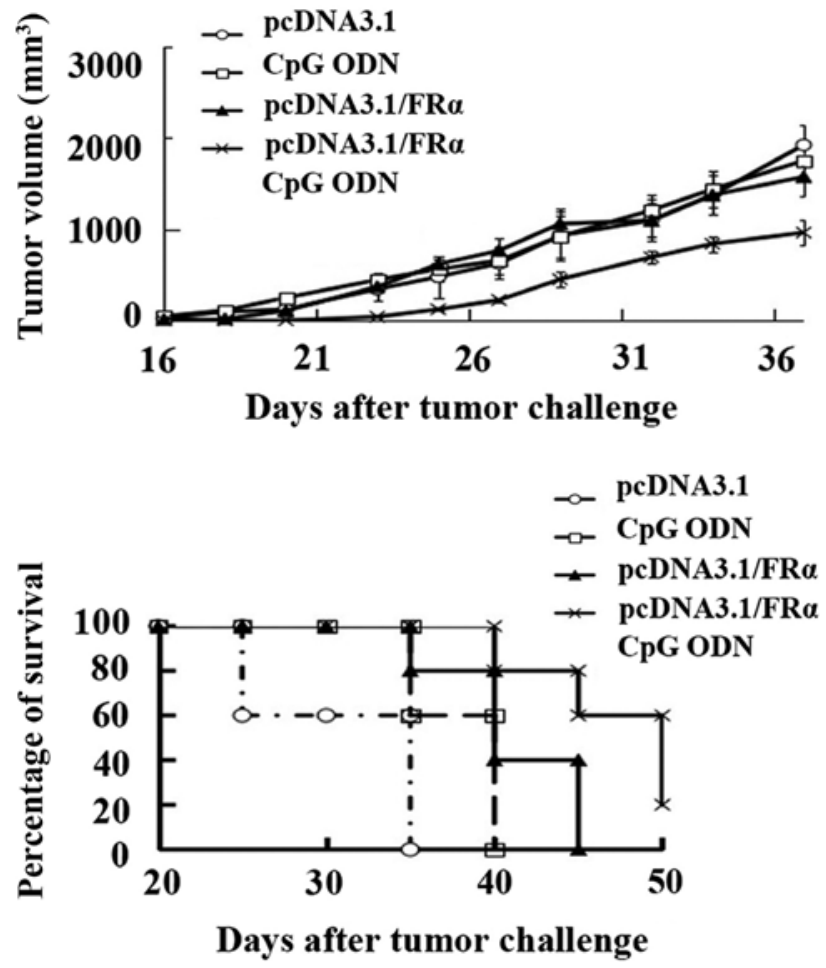

Figure 7. Therapeutic effect of mice immunized with pcDNA3.1/FR $\alpha$ alone or in combination with $\mathrm{CpG}$ ODNs. Female C57BL/6 mice were subcutaneously inoculated with $\mathrm{FR} \alpha$ transfected B16 cells and then were vaccinated with pcDNA3.1, CpG ODNs, pcDNA3.1/FR $\alpha$ and pcDNA3.1/FR $\alpha$ plus $\mathrm{CpG}$ ODNs. The vaccinations were at one-week interval and were given four times. The tumor volume was measured for 37 days after tumor challenge (upper panel). Mouse survival rates were monitored for 50 days (lower panel).

with pcDNA3.1/FR $\alpha$ was significantly higher than that of pcDNA3.1 group $(\mathrm{P}=0.013)$ and $\mathrm{CpG}$ ODN group $(\mathrm{P}=0.035)$. While $\mathrm{CpG}$ ODN can further increase this antigen specific lymphocyte proliferation comparing with pcDNA3.1/FR $\alpha$ group $(\mathrm{P}=0.037)$. As a mitogen for $\mathrm{T}$ cells, Con A stimulated non-specific $\mathrm{T}$ cell proliferation and $\mathrm{CpG}$ ODN enhanced the stimulating effect of ConA.

Protective effect of DNA vaccination in C57BL/6 mice. One week after the final immunization (week 5), the female C57BL/6 mice (4-6 weeks, 10 mice per group) were challenged subcutaneously with $2 \times 10^{5}$ FR $\alpha$ expressing B16 cells. Tumor growth was monitored after tumor challenge. As shown in Fig. 6, compared with the empty vector pcDNA3.1 control group, the mice immunized with $\mathrm{CpG}$ ODN did not show statistically reduced tumor growth whereas the pcDNA3.1/FR $\alpha$ immunized mice showed significantly reduced tumor growth $(\mathrm{P}=0.017)$. The mice injected with pcDNA3.1/FR $\alpha$ plus CpG ODN had reduced tumor growth with a very significant difference compared with the pcDNA3.1 control group $(\mathrm{P}=0.000281)$, the $\mathrm{CpG}$ ODN group $(\mathrm{P}=0.001)$ and the pcDNA3.1/FR $\alpha$ group $(\mathrm{P}=0.00579)$.

Furthermore the mice in pcDNA3.1 control group and CpG ODN group all died before day 38, whereas the mice immunized with pcDNA3.1/FR $\alpha$ died before day 45, showing a significant protective effect $(\mathrm{P}=0.0344)$. Mice immunized with pcDNA3.1/FR $\alpha$ plus CpG ODN (20\%) still survived at day 50 , showing a very significant difference compared with 
1

2

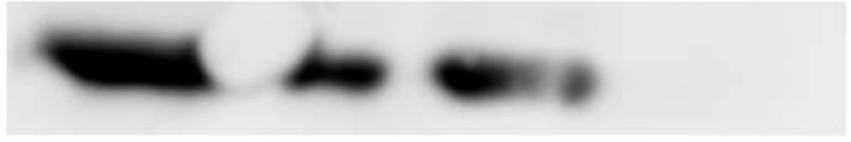

Figure 8. Analysis of FR $\alpha$ protein expression in tumors. Tumor tissues were collected and extracted proteins were resolved by SDS-PAGE. FR $\alpha$ expression was detected by western blotting. Lane 1 , tumors of the pcDNA3.1/FR $\alpha$ plus CpG ODNs group; lane 2, tumors of the pcDNA3.1/FR $\alpha$ group; lane 3, tumors of the pcDNA3.1 group; lane 4, tumor cells of untransfected B16 cells.

pcDNA3.1 control group $(\mathrm{P}=0.00569)$ and $\mathrm{CpG}$ ODN group $(\mathrm{P}=0.00453)$, and showing a significant difference compared with pcDNA3.1/FR $\alpha$ group $(\mathrm{P}=0.046)$.

Therapeutic effect of DNA vaccination in C57BL/6 mice. To evaluate the therapeutic effect of this DNA vaccine on an existing tumor, mice (10 per group) were inoculated with FR $\alpha$ expressing B16 cells on day 0 , and the mice were immunized with different reagents four times at one week intervals. Tumor growth was monitored daily after tumor inoculation. Fig. 7 shows that mice immunized with CpG ODN did not show reduced tumor growth compared with the empty vector pcDNA3.1 control group. The mice receiving pcDNA3.1/FR $\alpha$ did not show significantly reduced tumor growth $(\mathrm{P}=0.314)$ compared with the control group. The group injected with pcDNA3.1/FR $\alpha$ in combination with $\mathrm{CpG}$ ODN showed reduced tumor growth with a very significant difference compared with the pcDNA3.1 control group $(\mathrm{P}=0.000337)$ with the CpG ODN group ( $\mathrm{P}=0.00579)$, and a significant difference compared with the pcDNA3.1/FR $\alpha$ group $(\mathrm{P}=0.0251)$.

The therapeutic experiment was followed up with survival as the end point. The mice in the pcDNA3.1 control group all died before day 34 and all the mice in the CpG ODN group died before day 38 . The mice immunized with pcDNA3.1/FR $\alpha$ died before day 42 , without a statistically significant prolonged survival compared with pcDNA3.1 control group $(\mathrm{P}=0.13)$. For the mice immunized with pcDNA3.1/FR $\alpha$ plus $\mathrm{CpG}$ ODN, $20 \%$ of the mice survived until day 50, showing a significant difference compared with the pcDNA3.1 control group ( $\mathrm{P}=0.028)$, the $\mathrm{CpG}$ ODN group $(\mathrm{P}=0.031)$, and the pcDNA3.1/FR $\alpha$ group $(\mathrm{P}=0.0265)$.

Analysis of FR $\alpha$ protein expression in tumor tissues. After DNA vaccine treatment, tumors of mice from different treatment groups were obtained and western blotting was used to detect FR $\alpha$ expression in tumors. Fig. 8 shows that FR $\alpha$ expression was maintained in all the tested tumors.

\section{Discussion}

FR $\alpha$ is a tumor associated antigen. Because of its high expression in tumor cells and very limited expression in normal tissues, it is regarded as a promising target for cancer therapy (6).

Though DNA vaccination is an easy method based on its preparation, storage and safety compared with protein and peptide vaccines, its immunogenicity is usually low (11). Adjuvant is often needed to enhance its efficacy. Herein, we chose $\mathrm{CpG}$ ODN. It is known that $\mathrm{CpG}$ oligonucleotides are excellent adjuvants in murine models. When used in combination with peptide vaccines, it was as potent as the complete Freund's adjuvant regarding the induction of B cell and $\mathrm{T}$ cell responses. Furthermore, it is less toxic and it induces a T helper 1 (Th1) response (23). Mineral oil used with Freund's adjuvant kept a sustained release of antigen and at the same time made a local antigen depot (by entrapment of antigen in the mineral oil emulsion) where primed $\mathrm{CD}^{+} \mathrm{T}$ cells may accumulate instead of tumor targeting (24). Alum, the adjuvant that is used routinely in human vaccination, induces the less favorable Th2 response (25).

In this study, we constructed a recombinant plasmid encoding FR $\alpha$ as a DNA vaccine and detected its protective and therapeutic effect in mice models when it was used alone or in combination with $\mathrm{CpG}$ ODN. The DNA vaccine by itself or coinjected with $\mathrm{CpG}$ ODN both elicited humoral and cellular immune responses. As we expected, $\mathrm{CpG}$ ODN as an adjuvant enhanced both humoral and cellular immune reactivity. From the data of the humoral reactivity, although there was not a statistically significant increase in antibody titer after $\mathrm{CpG}$ ODN inclusion, we observed that serum from mice injected with pcDNA3.1/FR $\alpha$ plus CpG ODN always had a higher ELISA value compared with the pcDNA3.1/FR $\alpha$ group (data not shown). The pcDNA3.1/FR $\alpha$ and pcDNA3.1/FR $\alpha$ plus CpG ODN vaccines both elicited FR $\alpha$ specific CTL response (Fig. 4) and lymphocyte proliferation (Fig. 5). $\mathrm{CTL}$ is a typical $\mathrm{CD} 8^{+} \mathrm{T}$ cell reaction and antigen specific lymphocyte proliferation is a hallmark of $\mathrm{CD}^{+}$cell immunity together with antigen presenting cells. Normally, $\mathrm{CD} 4^{+}$ and $\mathrm{CD}^{+} \mathrm{T}$ cells perform their immune functions not in a parallel manner, but together with B cells and other immune cells, they form an immunological network. After activation by DC cells, FR $\alpha$ specific CD $4^{+} \mathrm{T}$ cells helped FR $\alpha$ specific $\mathrm{B}$ cells to activate and become plasma cells to produce FR $\alpha$ specific antibodies. The activated $\mathrm{CD} 4^{+} \mathrm{T}$ cells also helped $\mathrm{FR} \alpha$ specific $\mathrm{CD}^{+}{ }^{+} \mathrm{T}$ cells to be activated to elicit their $\mathrm{CTL}$ function. Furthermore, the $\mathrm{CD} 4^{+} \mathrm{T}$ cells might also secret cytokines to activate macrophages or other immune cells. All the above may contribute to the antitumor effect of the DNA vaccine.

In the mouse protective model, the DNA vaccine (pcDNA3.1/FR $\alpha$ ) showed a significant protecting effect against FR $\alpha$ expressing tumor in tumor growth and animal survival (Fig. 6). Whereas pcDNA3.1/FR $\alpha$ plus CpG ODN displayed a more potent effect than DNA vaccine alone, demonstrating the stimulating effect of $\mathrm{CpG}$ ODN on the immune system.

In the therapeutic model (Fig. 7), although vaccination by pcDNA3.1/FR $\alpha$ alone did not show significant effects on tumor growth and animal survival, pcDNA3.1/FR $\alpha$ with CpG ODN did show a significant therapeutic effect. This demonstrated a slow immune reactivity that DNA vaccine can elicit. It took some time for the FR $\alpha$ specific immunity to set up in mice. CpG ODN is an excellent adjuvant in mice and stimulation via TLR9 results in the rapid activation of the innate immune system that in turn supports the induction of an adaptive immune response. CpG ODN accelerated the induction of protective antibodies and generated higher and more persistent antibody titers with protein vaccines (26). Peptide based vaccines by themselves generally failed to elicit strong immune responses (27-30). In an early phase I trial that focused 
on CpG ODN as an adjuvant, 10-fold more antigen specific $\mathrm{T}$ cells were generated by patients with malignant melanoma immunized with the vaccine containing $\mathrm{CpG}$ versus the same vaccine lacking $\mathrm{CpG}$ (31). It was reported that recipients of the $\mathrm{CpG}$ ODN adjuvant vaccine developed Ag-specific CD8 $\mathrm{T}$ cells earlier and with significant higher frequency than the non- $\mathrm{CpG}$ group and the antitumor immunity arose more rapidly in patients vaccinated with $\mathrm{CpG}$ ODN (32). This is in line with our result. Actually, in immunotherapy of tumors, the situation of therapeutic group is closer to clinical practice. Our result confirmed that combined treatment of DNA vaccine and $\mathrm{CpG}$ ODN had potential in growth inhibition of FR-expressing tumors.

The B16 cell clones selected were stably transfected with pcDNA3.1/FR $\alpha$. It was reported that FR $\alpha$-transduced C26 cells gradually lost FR $\alpha$ expression and the remaining tumor cells without FR $\alpha$ expression were not attacked by FR $\alpha$ specific immune reactivity (33). Therefore, the tumor growth showed similar growth kinetics with the control group at a later stage. In the present protective and therapeutic animal experiments, mice treated with pcDNA3.1/FR $\alpha$ plus CpG ODN had a tumor which grew slower than that of the pcDNA3.1 or CpG ODN treatment group all through the experiment (37 days). Their growth rate neither speeded up nor showed a similar kinetics with the control group (Figs. 6 and 7). This indicated that the FR $\alpha$ expressing tumor cells did not lose their expression of FR $\alpha$ (Fig. 8), which is important in testing the effect of antitumor agents targeting FR $\alpha$. Our results also correlate with the clinical research that $\mathrm{FR} \alpha$ expression remains unchanged in different cancer after chemotherapy (19).

These work confirmed that $\mathrm{CpG}$ ODN was an excellent adjuvant even when administered in solution together with the DNA vaccine. It also confirmed that FR $\alpha$ represents an attractive candidate for cancer immunotherapy.

\section{Acknowledgements}

The present study was supported by the National Natural Science Foundation of China (grant no. 81301902) and Priority Academic Program Development of Jiangsu Higher Education Institutions (PAPD).

\section{References}

1. Delany I, Rappuoli R and De Gregorio E: Vaccines for the 21st century. EMBO Mol Med 6: 708-720, 2014.

2. Vanneman M and Dranoff G: Combining immunotherapy and targeted therapies in cancer treatment. Nat Rev Cancer 12: 237-251, 2012

3. Houghton AN: Cancer antigens: Immune recognition of self and altered self. J Exp Med 180: 1-4, 1994.

4. Wolff JA, Malone RW, Williams P, Chong W, Acsadi G, Jani A and Felgner PL: Direct gene transfer into mouse muscle in vivo. Science 247: 1465-1468, 1990.

5. Fioretti D, Iurescia S, Fazio VM and Rinaldi M: DNA vaccines: Developing new strategies against cancer. J Biomed Biotechnol 2010: 174378, 2010

6. Li L, Saade F and Petrovsky N: The future of human DNA vaccines. J Biotechnol 162: 171-182, 2012.

7. Latz E, Schoenemeyer A, Visintin A, Fitzgerald KA, Monks BG, Knetter CF, Lien E, Nilsen NJ, Espevik T and Golenbock DT: TLR9 signals after translocating from the ER to CpG DNA in the lysosome. Nat Immunol 5: 190-198, 2004.

8. Krieg AM: Therapeutic potential of Toll-like receptor 9 activation. Nat Rev Drug Discov 5: 471-484, 2006.
9. Klinman DM, Currie D, Lee G, Grippe V and Merkel T: Systemic but not mucosal immunity induced by AVA prevents inhalational anthrax. Microbes Infect 9: 1478-1483, 2007.

10. Ohno S, Okuyama R, Aruga A, Sugiyama H and Yamamoto M: Phase I trial of Wilms' Tumor 1 (WT1) peptide vaccine with GM-CSF or CpG in patients with solid malignancy. Anticancer Res 32: 2263-2269, 2012.

11. Mutwiri GK, Nichani AK, Babiuk S and Babiuk LA: Strategies for enhancing the immunostimulatory effects of $\mathrm{CpG}$ oligodeoxynucleotides. J Control Release 97: 1-17, 2004.

12. Vollmer $\mathbf{J}$ and Krieg AM: Immunotherapeutic applications of CpG oligodeoxynucleotide TLR9 agonists. Adv Drug Deliv Rev 61: 195-204, 2009.

13. Halperin SA, Van Nest G, Smith B, Abtahi S, Whiley H and Eiden JJ: A phase I study of the safety and immunogenicity of recombinant hepatitis B surface antigen co-administered with an immunostimulatory phosphorothioate oligonucleotide adjuvant. Vaccine 21: 2461-2467, 2003.

14. Elnakat $\mathrm{H}$ and Ratnam M: Role of folate receptor genes in reproduction and related cancers. Front Biosci 11: 506-519, 2006

15. Parker N, Turk MJ, Westrick E, Lewis JD, Low PS and Leamon CP: Folate receptor expression in carcinomas and normal tissues determined by a quantitative radioligand binding assay. Anal Biochem 338: 284-293, 2005.

16. Basal E, Eghbali-Fatourechi GZ, Kalli KR, Hartmann LC, Goodman KM, Goode EL, Kamen BA, Low PS and Knutson KL: Functional folate receptor alpha is elevated in the blood of ovarian cancer patients. PLoS One 4: e6292, 2009.

17. Kalli KR, Oberg AL, Keeney GL, Christianson TJ, Low PS, Knutson KL and Hartmann LC: Folate receptor alpha as a tumor target in epithelial ovarian cancer. Gynecol Oncol 108: 619-626, 2008.

18. Toffoli G, Cernigoi C, Russo A, Gallo A, Bagnoli M and Boiocchi M: Overexpression of folate binding protein in ovarian cancers. Int J Cancer 74: 193-198, 1997.

19. Despierre E, Lambrechts S, Leunen K, Berteloot P, Neven P, Amant F, O'Shannessy DJ, Somers EB and Vergote I: Folate receptor alpha (FRA) expression remains unchanged in epithelial ovarian and endometrial cancer after chemotherapy. Gynecol Oncol 130: 192-199, 2013.

20. Ebel W, Routhier EL, Foley B, Jacob S, McDonough JM, Patel RK, Turchin HA, Chao Q, Kline JB, Old LJ, et al: Preclinical evaluation of MORAb-003, a humanized monoclonal antibody antagonizing folate receptor-alpha. Cancer Immun 7: 6-13, 2007.

21. Armstrong DK, White AJ, Weil SC, Phillips M and Coleman RL: Farletuzumab (a monoclonal antibody against folate receptor alpha) in relapsed platinum-sensitive ovarian cancer. Gynecol Oncol 129: 452-458, 2013.

22. Walters CL, Arend RC, Armstrong DK, Naumann RW and Alvarez RD: Folate and folate receptor alpha antagonists mechanism of action in ovarian cancer. Gynecol Oncol 131: 493-498, 2013.

23. Chu RS, Targoni OS, Krieg AM, Lehmann PV and Harding CV: $\mathrm{CpG}$ oligodeoxynucleotides act as adjuvants that switch on T helper 1 (Th1) immunity. J Exp Med 186: 1623-1631, 1997.

24. Hailemichael Y and Overwijk WW: Cancer vaccines: Trafficking of tumor-specific $\mathrm{T}$ cells to tumor after therapeutic vaccination. Int J Biochem Cell Biol 53: 46-50, 2014.

25. Lindblad EB: Aluminium compounds for use in vaccines. Immunol Cell Biol 82: 497-505, 2004.

26. Cooper CL, Davis HL, Angel JB, Morris ML, Elfer SM, Seguin I, Krieg AM and Cameron DW: CPG 7909 adjuvant improves hepatitis B virus vaccine seroprotection in antiretroviral-treated HIV-infected adults. AIDS 19: 1473-1479, 2005.

27. Perales MA, Yuan J, Powel S, Gallardo HF, Rasalan TS, Gonzalez C, Manukian G, Wang J, Zhang Y, Chapman PB, et al: Phase I/II study of GM-CSF DNA as an adjuvant for a multipeptide cancer vaccine in patients with advanced melanoma. Mol Ther 16: 2022-2029, 2008.

28. Krug LM, Dao T, Brown AB, Maslak P, Travis W, Bekele S, Korontsvit T, Zakhaleva V, Wolchok J, Yuan J, et al: WT1 peptide vaccinations induce CD4 and CD8 T cell immune responses in patients with mesothelioma and non-small cell lung cancer. Cancer Immunol Immunother 59: 1467-1479, 2010.

29. Barve M, Bender J, Senzer N, Cunningham C, Greco FA, McCune D, Steis R, Khong H, Richards D, Stephenson J, et al: Induction of immune responses and clinical efficacy in a phase II trial of IDM-2101, a 10-epitope cytotoxic T-lymphocyte vaccine, in metastatic non-small-cell lung cancer. J Clin Oncol 26: 4418-4425, 2008. 
30. Vansteenkiste J,Zielinski M,Linder A, Dahabreh J, Gonzalez EE, Malinowski W, Lopez-Brea M, Vanakesa T, Jassem J, Kalofonos H, et al: Adjuvant MAGE-A3 immunotherapy in resected non-small-cell lung cancer: Phase II randomized study results. J Clin Oncol 31: 2396-2403, 2013.

31. Baumgaertner P, Jandus C, Rivals JP, Derré L, Lövgren T, Baitsch L, Guillaume P, Luescher IF, Berthod G, Matter M, et al: Vaccination-induced functional competence of circulating human tumor-specific CD8 T-cells. Int J Cancer 130: 2607-2617, 2012 .
32. Speiser DE, Liénard D, Rufer N, Rubio-Godoy V, Rimoldi D, Lejeune F, Krieg AM, Cerottini JC and Romero P: Rapid and strong human $\mathrm{CD} 8^{+} \mathrm{T}$ cell responses to vaccination with peptide, IFA, and $\mathrm{CpG}$ oligodeoxynucleotide 7909. J Clin Invest 115: 739-746, 2005

33. Neglia F, Orengo AM, Cilli M, Meazza R, Tomassetti A, Canevari S, Melani C, Colombo MP and Ferrini S: DNA vaccination against the ovarian carcinoma-associated antigen folate receptor alpha (FRalpha) induces cytotoxic T lymphocyte and antibody responses in mice. Cancer Gene Ther 6: 349-357, 1999. 